\title{
Targeting Ligands Deliver Model Drug Cargo into the Central Nervous System Along Autonomic Neurons
}

Drew L. Sellers ${ }^{1,2}$, James-Kevin Y. Tan ${ }^{1}$, Julio Marco B. Pineda ${ }^{1}$, David J. Peeler ${ }^{1}$, Veronica L. Porubsky ${ }^{1}$, Brynn R. Olden ${ }^{1}$, Stephen J. Salipante ${ }^{4}$, Suzie H. Pun ${ }^{1,3}$

${ }^{1}$ Department of Bioengineering, University of Washington, Seattle, Washington, 98195, USA.

${ }^{2}$ Institute for Stem Cell and Regenerative Medicine, University of Washington, Seattle, Washington, 98195, USA.

${ }^{3}$ Molecular Engineering and Sciences Institute, University of Washington, Seattle, Washington, 98195, USA

${ }^{4}$ Department of Laboratory Medicine, University of Washington, Seattle, Washington 98195, United States

SUPPORTING CONTENT 


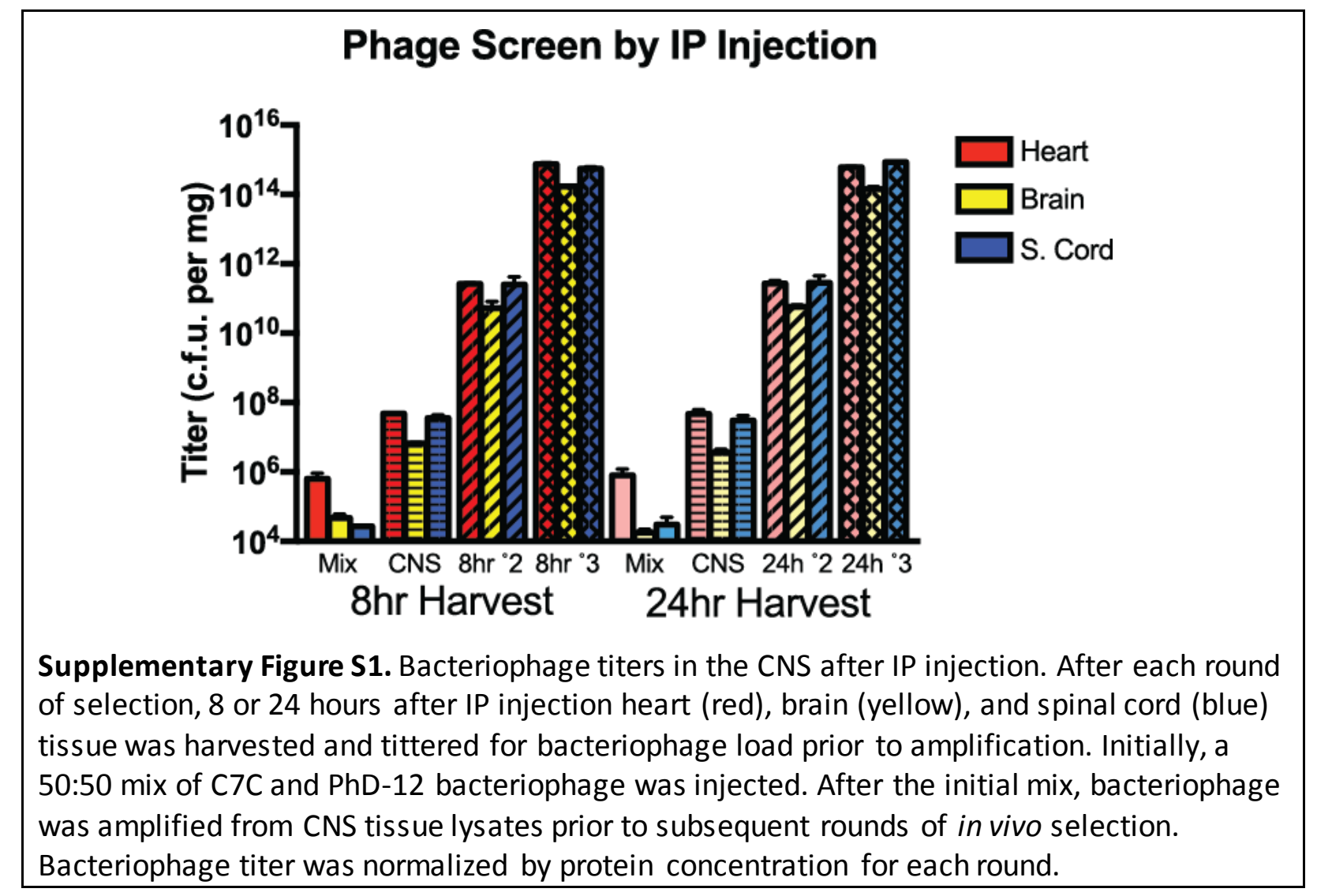




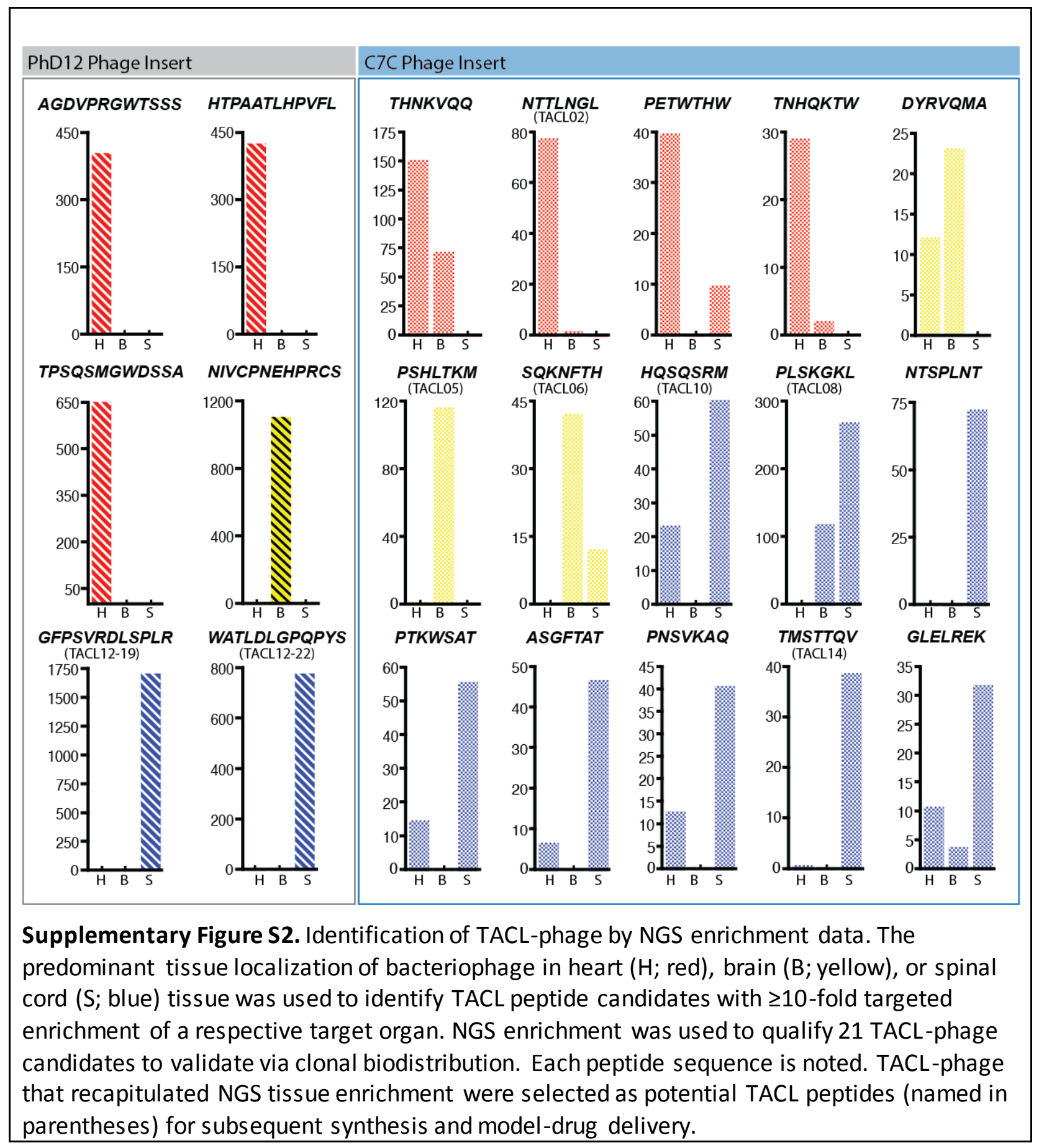




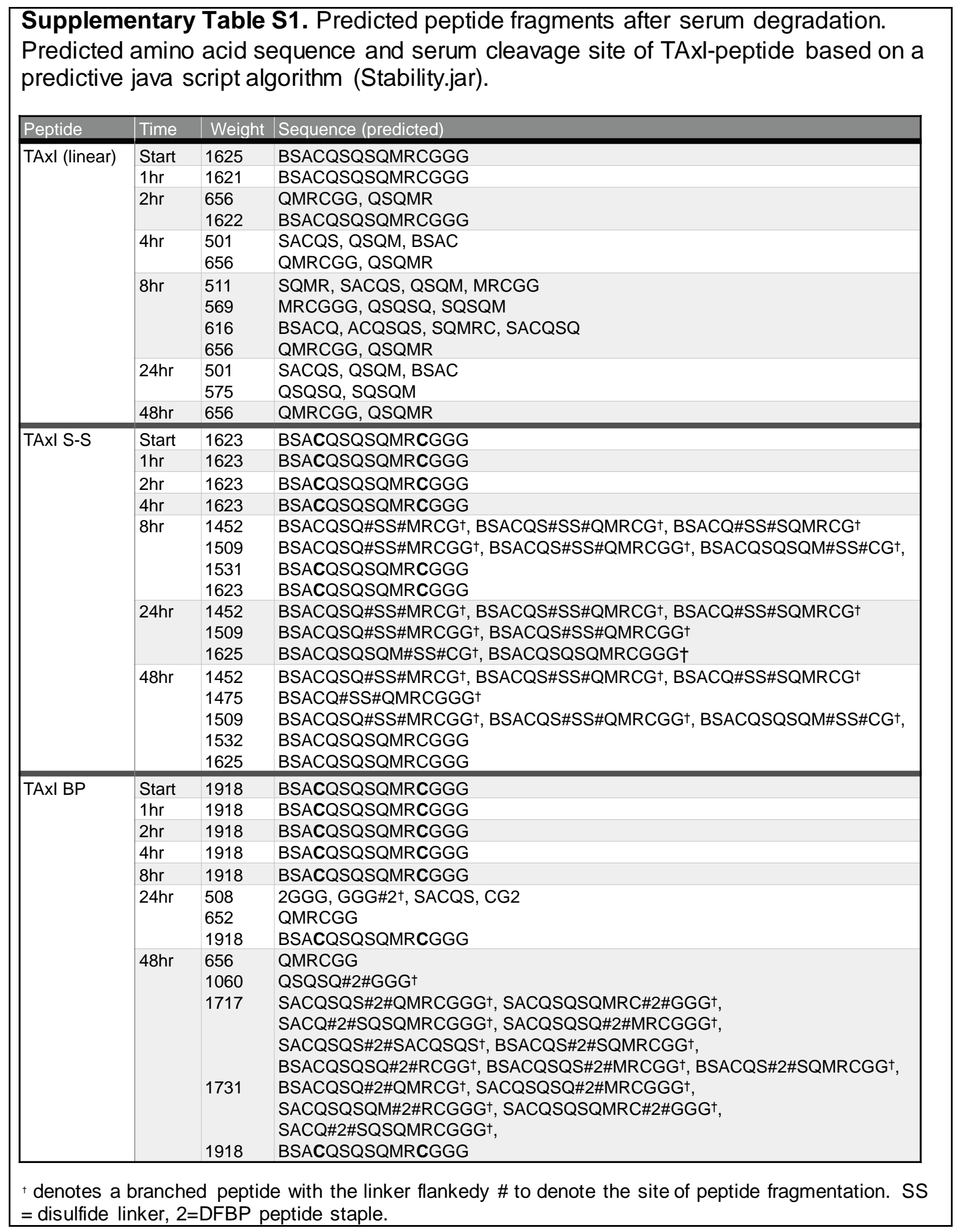


Supplementary Table S2. Blastp search results obtained by a query of TACL08 insert. Select representatives of the 129 blast hits for the amino acid sequence unique to TACL08 phage are listed.

\begin{tabular}{|l|c|c|c|}
\hline \multicolumn{1}{|c|}{ Name } & $\begin{array}{c}\text { Query } \\
\text { Cover }\end{array}$ & $\begin{array}{c}\text { Max } \\
\text { ident }\end{array}$ & Accession \\
\hline vomeronasal 1 receptor Vmn1r156 & $100 \%$ & $78 \%$ & NP 001160626.1 \\
\hline gamma-aminobutyric acid receptor & $86 \%$ & $85 \%$ & $\underline{\text { EDL23325.1 }}$ \\
\hline Ubiquitin-protein ligase & $85 \%$ & $100 \%$ & $\underline{\text { ABK59000.1 }}$ \\
\hline dynein heavy chain 9, axonemal & $71 \%$ & $100 \%$ & $\underline{\text { NP 001093103.1 }}$ \\
\hline hemicentin-1 precursor & $85 \%$ & $83 \%$ & $\underline{\text { NP 001019891.2 }}$ \\
\hline $\begin{array}{l}\text { serine/threonine-protein } \\
\text { phosphatase 2A regulatory subunit B }\end{array}$ & $85 \%$ & $83 \%$ & $\underline{\text { NP 001154834.1 }}$ \\
\hline protocadherin-23 & $71 \%$ & $100 \%$ & $\underline{\text { NP 001344094.1 }}$ \\
\hline centrosomal protein X2 & $71 \%$ & $100 \%$ & $\underline{\text { XP 006510198.1 }}$ \\
\hline TASOR isoform 1 & $66 \%$ & $83 \%$ & $\underline{\text { NP 001108351.1 }}$ \\
\hline
\end{tabular}

